Journal Of Agriculture and Social Research (JASR) Vol. 8, No.1, 2008

\title{
EFFECT OF TECHNOLOGICAL CHANGE ON OUTPUT AND FACTOR SHARES IN POTATO PRODUCTION IN JOS PLATEAU AREA OF PLATEAU STATE, NIGERIA
}

\author{
ANIEDU, O. C AND ONYENWEAKU, C.E
}

\begin{abstract}
This study was carried out in four Local Government Areas in Plateau State - Jos South, Bokkos, Mangu and Barkin Ladi, which were randomly selected from eight noted for potato production. The sample size was 182 used in the analysis of the data. The primary data were collected using structured questionnaires forthnightly. Two improved potato varieties (Nicola and Lady Christy) and one local variety (Empi) were used in this study. The production systems were Furrow/Flood Irrigation and Manual watering.The factor shares in the cost of production were estimated and the technical change biases measured. The factor shares were estimated using a normalized CobbDouglas profit function to indirectly estimate the partial elasticities of the Cobb-Douglas production function with constant returns to scale. Capital had the highest cost-share of 57.2\% under the Manual watering production system, while labour had the least (12.5\%). The technological change biases introduced by different potato varieties under the different production systems were factor-saving for labour and fertilizer but factor-using for land and capital in Nicola under Furrow/Flood irrigation production system. Normalized Cobb-Douglas profit function indirectly estimated the partial elasticities of the Cobb-Douglas production functions with constant returns to scale for potato in Jos Plateau.
\end{abstract}

\section{Keywords: Technological change, Cobb-Douglas and Profit functions, Factor shares}

\section{INTRODUCTION}

According to Okonkwo et al (1995a), the establishment of Irish Potato Programme in National Root Crops Research Institute, Umudike at Kuru, Jos in 1976, marked the beginning of rapid expansion of potato production in Nigeria. To tackle the problems of inadequate supply of good quality seed, storage, low productivity of potato and control of the major potato diseases and pests, the programme adopted the following strategies:

(i) breeding in Nigeria for high yielding and disease resistant varieties.

(ii) introduction of proven varieties/clones and tuber families from other countries and screening them for high yields and resistance to local diseases.

(iii) multiplication and distribution of proven varieties to farmers to replace the old degenerated and low yielding varieties.

(iv) improvements in cultural management of potato through research.

(v) increased extension activity of the potato programme and Plateau State ADP, to identify and find solutions to farmers production problems through the monthly technology review meetings and research.

(vi) development of storage structures for use by farmers and

(vii) training of extension and research staff involved in potato projects.

Figure 1 is a graphical presentation of potato production and area harvested in Nigeria between 1984 and 2004. 


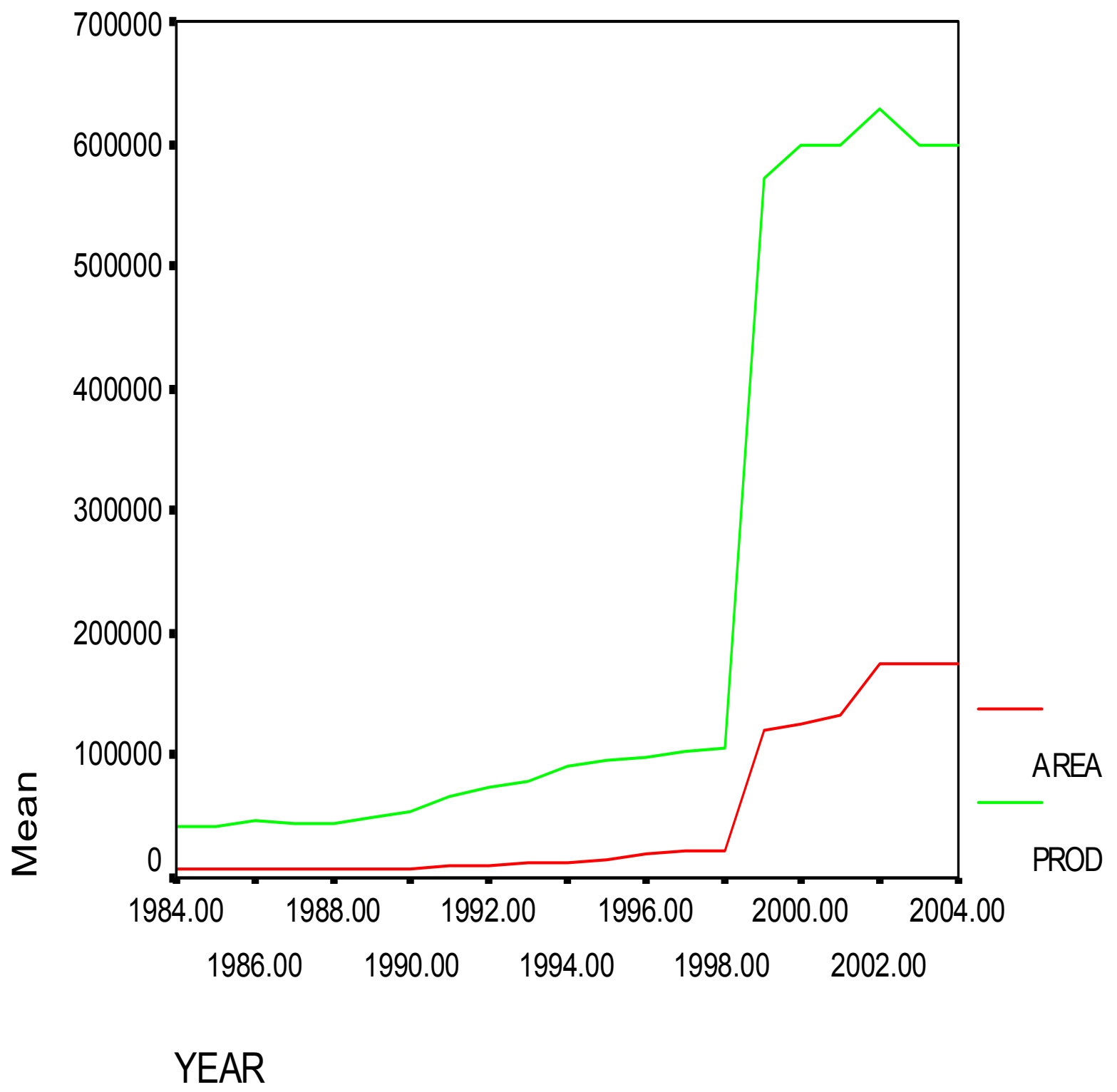

Fig. 1 Potato Production and Area Harvested in Nigeria (1984 - 2004)

In Fig. 1, it is observed that there was a progressive increase in both potato production and area devoted to potato production in the study area. This was spectacular between 1998 and 2002 for the following reasons: (a) The sustained activities of National Agricultural Land Development Authority (NALDA) which extended her operations to thirty States of the Federation, encouraged farmers to bring more land under cultivation.

(b) the supply of high quality seeds/seedlings that are high yielding and disease tolerant.

(c) intensification of on-farm adaptive research by some relevant agencies and the provision of improved extension services to farmers.

(d) expansion of potato production from Jos Plateau to Mambilla and Biu Plateaus. Also potato is now produced in Kano, Kaduna, Sokoto, Taraba, Adamawa and Borno States in the dry season.

(e) favourable weather conditions. 
(f) improved level of funding of ADPs resulting in increased activities. Hence more land were brought under irrigation.

Potato production was introduced into Jos Plateau Nigeria in the 1940s' by the colonial government (Stanton, 1960; Ifenkwe, 1981). Since then, potato production remained in the hands of small holder farmers. These farmers obtain an average of $4.65 \mathrm{t} / \mathrm{ha}$ which is about $\mathbf{4 0 \%}$ of the potential tuber yield obtained in research fields. Reasons for the relatively low net return per hectare of potato on small-holder farms include: land area cultivated, low soil fertility, poor management practices, prevalence of pests and diseases, poorly organized seed supply and tuber storage problems (Fawole and Akoroda, 2000).

To address the problem of potato production in Nigeria, the potato programme of National Root Crops Research Institute, Umudike was established at Kuru, Jos in 1976. (Okonkwo et al 1995a). According to Ifenkwe, 1981 and Okonkwo, 1992, farmers yields have progressively increased from 5 tonnes per hectare in 1973 to about 10 tonnes per hectare in1986. The improved yields reflect the gains which have been made over the years in breeding and selection for high yielding varieties with resistance to major pests and diseases, improved quality of planting materials and better husbandry practices in Jos plateau.

Alshi et al (1981), used profit function approach to derive factor shares in cotton production in India. The results showed that the share of land to be the largest for all the varieties, ranging from 0.452 for the local variety to 0.54 for the improved American variety. The share of labour decreased substantially as one moved from old to new technology. However, Andersen (1982), found out that factor combinations and factor shares in agriculture depend on a number of factors, such as resource endowment of the region, the type of crop grown, level of technology used, factor prices and government policies.

The question now is how has the introduction of high-yielding potato varieties, fertilizers, irrigation facilities etc into Jos Plateau affected potato production and factor shares in the study area? The specific objectives of the study are:

(i) to estimate factor shares according to production systems and potato varieties and

(ii) to determine the nature of the technological change biases for the various factors of production by production systems and potato varieties.

\section{METHODOLOGY}

The study was carried out in Plateau State. Jos Plateau is located between Longitude $8^{\circ} 40^{\prime}$ and $9^{\circ} 50^{\prime} \mathrm{E}$ and latitude $9^{\circ}$ and $10^{\circ} 45^{\prime} \mathrm{N}$ It is almost at the centre of Nigeria and has borders with Bauchi State in the North-East, Kano State in the North, Kaduna State in the North-West. In the South, it has boundary with Benue and Taraba States (Okonkwo et al 1995b).

Jos Plateau's elevation ranges from $1,100 \mathrm{~m}-1,400 \mathrm{~m}$ above sea level and is the second highest highland in Nigeria after the Mambilla Plateau $(1,800 \mathrm{~m})$. The highest temperatures of about $30^{\circ} \mathrm{C}$ are recorded in the months of March to May each year while the lowest temperatures of about $20^{\circ} \mathrm{C}$ are between December and January. Potato requires an optimum temperature of $15^{\circ} \mathrm{C}$ for tuber formation. Jos Plateau meets this condition in both the rainy and dry seasons. In the dry season, potato is planted in late October or early November to take advantage of the low December and January temperatures for tuberization. Generally, potato is planted between the last week of April and end of May each year. (Okonkwo et al., 1995b). 
A total of 240 Farm households were chosen randomly from four Local Government Areas out of the eight that make up Jos Plateau. i.e. Bokkos, Mangu, Barkin Ladi and Jos South. Jos Plateau was purposively chosen because potato is the most important crop grown there. First, four Local Government Areas were randomly selected from the eight in Jos Plateau. Two villages were randomly selected from each Local Government Area in the second stage, thirty households were randomly selected from each village in the third stage. This gave a total of 240 farm households. The sampling frame was the list of potato farmers for each Local Government Area/Village selected, obtained from the Plateau State Agricultural Development Programme (PADP).

Primary data were collected using structured questionnaires, which were distributed to the farm households by the Block Extension Agents(BEAs) in the four Local Government Areas selected for the study. Data were collected from the households fortnightly by the four BEAs involved in the data collection for this study. Data collection lasted from $7^{\text {th }}$ November, 2005 to $3^{\text {rd }}$ May, 2006. However, only 182 potato farmers responded to my interview.

\section{Derivation of Profit Function from Production Function}

According to Sankhayan (1988), a production function with $m$ variable inputs, $X_{1}, X_{2}, \ldots . ., X_{m}$ and $n$ fixed inputs, $Z_{1}, Z_{2}, \ldots . Z_{n}$ is related to output, i.e. $Y=f\left(X_{1}, X_{2}, \ldots, X_{m}, Z_{1}, Z_{2}, \ldots . . Z_{n}\right)$

In the short run, the opportunity cost of fixed inputs is zero. Therefore, the producer needs only to maximize the returns to fixed inputs. The resulting returns, also called variable profits ( $\pi^{*}$ ), to fixed inputs in respect of the production function given above can thus be written as:

$\pi^{`}=\operatorname{Py~} f\left(X_{1}, X_{2}, \ldots X_{m}, Z_{1}, Z_{2}, \ldots \ldots Z_{n}\right)-\sum P_{i} X_{i}$

Where $P_{y}$ is the price of output and $\mathrm{Pi}$ is the price per unit of the ith variable input, $\mathrm{i}=1,2 \ldots \mathrm{m}$ For maximization of $\pi$ in the short run, take the first order partial derivatives with respect to the variable inputs and equate them to zero each. Thus, the partial derivative from the equation above with respect to $X_{i}, i=1,2 \ldots . . m$, equated to zero is given by $d y_{i} / d_{x_{i}}=P_{y} f_{i}=P_{i} \ldots .9$

$\partial \pi^{\prime} / \partial \mathrm{X}_{\mathrm{i}}=\mathrm{P}_{\mathrm{y}} \mathrm{f}_{\mathrm{i}}=\mathrm{Pi}$

Where fi denotes the first order partial derivative with respect to the ith input.

\section{Normalized Profit Function}

Realizing that the profit maximizing levels of variable inputs $\left(\mathrm{X}_{\mathrm{i}}^{*}\right)$ would remain unaltered even if both sides of the profit equation are divided by a scalar, ie price of the output $\left(\mathrm{P}_{\mathrm{y}}\right)$. Thus the profit equation is transformed into $\pi^{\prime} / P_{y}=\pi=f\left(X_{1}, X_{2}, \ldots . X_{m}, Z_{1}, Z_{2}, \ldots . Z_{n}\right)-1 / P_{y} \sum P_{i} X_{i}$

Note, the $\pi$ is the normalized profit, which is related to relative input prices unlike the profit function which is related to the actual prices of inputs and the price of the output.

According to Alshi et al (1981), Lau and Yotopoulos (1972), the partial elasticities of a Cobb-Douglas production function with constant returns to scale are the factor shares in output and this can also be used for examining the technical change biases with many factors of production. Following Alshi et al (1981), normalized Cobb-Douglas profit equation can be used to indirectly estimate the partial elasticities of the Cobb-Douglas production function with constant returns to scale.

The Cobb-Douglas production functions for various potato varieties and production systems with the usual neo-classical properties are stated as follows 


$$
\begin{aligned}
& \mathrm{Y}=\mathrm{AX}_{1}{ }^{\mathrm{a} 1} \mathrm{X}_{2}{ }^{\mathrm{a} 2} \mathrm{X}_{3}{ }^{\mathrm{a} 3} \mathrm{X}_{4}{ }^{\mathrm{a} 4} \mathrm{X}_{5}{ }^{\mathrm{a} 5} \mathrm{U}_{\mathrm{i}} \\
& \text { This equation can be rewritten as } \\
& \mathrm{L}_{\mathrm{n}} \mathrm{Y}=\mathrm{L}_{\mathrm{n}} \mathrm{A}+\mathrm{a}_{1} \mathrm{~L}_{\mathrm{n}} \mathrm{X}_{1}+\mathrm{a}_{2} \mathrm{~L}_{\mathrm{n}} \mathrm{X}_{2}+\mathrm{a}_{3} \mathrm{~L}_{\mathrm{n}} \mathrm{X}_{3}+\mathrm{a}_{4} \mathrm{~L}_{\mathrm{n}} \mathrm{X}_{4}+\mathrm{a}_{5} \mathrm{~L}_{\mathrm{n}} \mathrm{X}_{5}+\mathrm{U}_{\mathrm{i}}
\end{aligned}
$$

The variables are as previously defined.

$\mathrm{A}$ is the constant term, $\mathrm{a}_{1-\mathrm{a} 5}$ are the production elasticity coefficients of the respective inputs to be estimated and $\mathrm{U}_{\mathrm{i}}$ is the error term. The normalized profit equation for this study can be written as:

$$
\pi^{*} \quad=\quad A^{*}(W / P)^{b 1}\left(P_{f} / P\right)^{b 2} X_{4}{ }^{b 3} X_{5}{ }^{b 4}
$$

Where: $W=$ Wage in $¥, P=$ potato price $\$ / \mathrm{kg}, \mathrm{P}_{\mathrm{f}}=$ price of fertilizer $\$ / \mathrm{kg}, \mathrm{X}_{4}=$ Capital input in naira/ hectare and $\mathrm{X}_{5}=$ Farm size in hectare.

$$
\begin{aligned}
& A^{*}=\left(1-a_{1}\right) A_{a 1}^{\Theta a}{ }_{a}, b_{1}=-a_{1} \Theta, b_{2}=a_{2} \Theta, b_{3}=b_{3} \Theta, b_{4}=a_{4} \Theta \\
& \Theta=\left(1-a_{1}\right)^{-1}, \pi^{*}=\pi^{\prime} p=\text { Normalized profit }
\end{aligned}
$$

$\pi=$ Profit defined as current revenue less current wage plus cost of fertilizer in Naira. A restriction was imposed on the normalized profit equation regarding the assumption of constant returns to scale ie $b_{3}+b_{4}=1$.

\section{Measurement of Technical Change Biases}

Following Alshi et al (1981), the partial elasticities of the potato production functions with constant returns to scale was used to measure the technical change biases of the factors of production. The stated equation below was used:

$$
\mathrm{B}_{\mathrm{i}}=\underset{\left(\mathrm{a}_{\mathrm{i}}\right)_{\mathrm{N}}-\left(\mathrm{a}_{\mathrm{i}}\right)_{0}}{\left(\mathrm{a}_{\mathrm{O}}\right.}
$$

Where:

$B_{i}$ is the calculated technical change bias, $a_{i}$ is the output elasticity of ith factor and the subscripts 'N' and 'O' stand for "new" and "old" production technologies respectively. According to Hick's definition, the technical change is ith input-saving if $\mathrm{Bi}<\mathrm{O}$, neutral if $\mathrm{Bi}=\mathrm{O}$ and input-using if $\mathrm{Bi}$ $>\mathrm{O}$.

\section{RESULTS AND DISCUSSION \\ Estimation of Cobb-Douglas Profit Function}

Tables 1 and 2 present the estimated Cobb-Douglas profit function for Nicola, Lady Christy and Empi for the two production systems. The imposed restriction on these profit functions for constant returns to scale was that $b_{3}+b_{4}=1$, where $b_{3}$ and $b_{4}$ are the estimated coefficients for capital and land. The profit function was decreasing in wage as expected but increasing in fertilizer, land and capital in the Furrow/Flood irrigation production system. However, in the Manual watering production system, the profit function was decreasing in wage and fertilizer while increasing in land and capital. 
Table 1: Estimated Profit function for Potato under Furrow/Flood Irrigation Production System.

\begin{tabular}{lllll}
$\begin{array}{l}\text { Items } \\
\text { Normalized } \\
\text { profit function }\end{array}$ & Parameter & Nicola & Lady Christy & Empi \\
Constant & & & & \\
& LnA & $-13.718^{*}$ & -3.091 & -0.694 \\
Normalized & & $(-1.477)$ & $(-0.602)$ & $(-0.117)$ \\
Wage ( N ) & & -1.101 & $-1.974^{*}$ & 2.327 \\
& & $(-0.079)$ & $(-1.467)$ & $(0.785)$ \\
Fertilizer & b2 & 1.717 & & \\
Price(N) & & $(0.608)$ & $(2.502)$ & 1.257 \\
Capital (N) & b3 & $0.513 * * *$ & $0.517 * *$ & $(0.434)$ \\
& & $(2.994)$ & $(2.079)$ & 0.513 \\
Land (Ha) & b4 & 0.487 & $0.483 *$ & $(0.630)$ \\
& & $(0.027)$ & $(1.290)$ & 0.487 \\
$R^{2}$ & & 0.239 & 0.314 & $(0.989)$ \\
F & & 1.685 & 2.426 & 0.154 \\
\hline
\end{tabular}

Source: Field survey, 2006. ***Significant at 1\% level,** Significant at $5 \%$ level *Significant at $\mathbf{1 0 \%}$ level

The values in parentheses are $t$-values for the estimated parameters

The imposed restriction is that $b_{3}+b_{4}=1$

Table 2: Estimated Profit function for Potato under Manual Watering production System Items Parameter Nicola Lady Christy Empi

Normalized

Profit function

Constant LnA

$18.522 * * *$

$-14.201$

17.956

(3.088)

$(-0.900)$

(0.854)

Normalized

$-1.043$

0.111

$-2.448^{*}$

Wage ( N )

$(-0.179)$

(0.689)

$(-1.285)$

Fertilizer

$-0.856$

$-2.478$

3.004

Price $(\mathrm{N})$

$(-1.109)$

Capital(N)

$0.515^{* *}$

$(-0.239)$

(0.483)

(1.726)

Land(Ha)

0.485

$0.846^{*}$

0.518

(1.572)

(0.903)

(0.359)

0.154

0.483

$\mathrm{R}^{2}$

0.293

(0.621)

(0.751)

F

2.034

0.284

0.216

Source: $\quad$ Field survey, $2006 * *$ Significant at $1 \%$ level $* *$ Significant at $5 \%$ level *Significant at $10 \%$ level.

The values in parentheses are $t$ - values of the estimated parameters.

The imposed restriction is that $b_{3}+b_{4}=1$

Factor Shares In Potato Production

Tables 3 and 4 show the result of an indirect estimation of Cobb-Douglas production function with constant returns to scale for potato under Furrow/flood irrigation and Manual watering production systems. The partial elasticities of these production functions give the factor shares in output. In the 
furrow/flood irrigation production system, the share of fertilizer in potato production was the maximum for all varieties of potato, ranging from 0.300 for Lady Christy to 0.378 for Empi. However, in the Manual watering production system the share of capital was the maximum ranging from 0.252 for Nicola and 0.572 for Lady Christy. The improved varieties of potato required intensive application of capital inputs therefore the share of capital in Lady Christy was high.

Table 3: Indirect estimates of Production Function for Potato Under furrow/flood irrigation Production System.

\begin{tabular}{|c|c|c|c|c|}
\hline \multirow[b]{2}{*}{ Input } & \multirow[b]{2}{*}{ Parameters } & \multicolumn{2}{|c|}{ Estimates of Production } & \multirow{2}{*}{$\begin{array}{l}\text { Elasticities } \\
\text { Empi }\end{array}$} \\
\hline & & Nicola & Lady Christy & \\
\hline Constant & A & 36.358 & 6.620 & 2.736 \\
\hline Labour input & a1 & 0.211 & 0.364 & 0.321 \\
\hline Fertilizer input & a2 & 0.317 & 0.300 & 0.378 \\
\hline Capital input & a3 & 0.244 & 0.174 & 0.154 \\
\hline Land & $\mathrm{a} 4$ & 0.228 & 0.162 & 0.147 \\
\hline
\end{tabular}

Source: $\quad$ Field Survey, 2006

Table 4: Indirect Estimates of Production Function for Potato Under Manual Watering Production System

\begin{tabular}{lllll}
\hline \multirow{2}{*}{$\begin{array}{l}\text { Pnput } \\
\text { Constant }\end{array}$} & Parameters & Estimates of Production Elasticities \\
Labour input & $\mathrm{A}$ & 51.997 & 69.411 & 63.709 \\
Fertilizer input & $\mathrm{a} 1$ & 0.192 & 0.125 & 0.162 \\
Capital & $\mathrm{a} 2$ & 0.319 & 0.168 & 0.229 \\
Land & $\mathrm{a} 3$ & 0.252 & 0.572 & 0.315 \\
\hline Sourcer & & 0.237 & 0.135 & 0.294 \\
\hline
\end{tabular}

Source: $\quad$ Field Survey, 2006 
Journal Of Agriculture and Social Research (JASR) Vol. 8, No.1, 2008

Nature of Factor Biases in Technical change in Potato production.

Table 5: Nature of Factor Biases in Technical Change in Potato Production

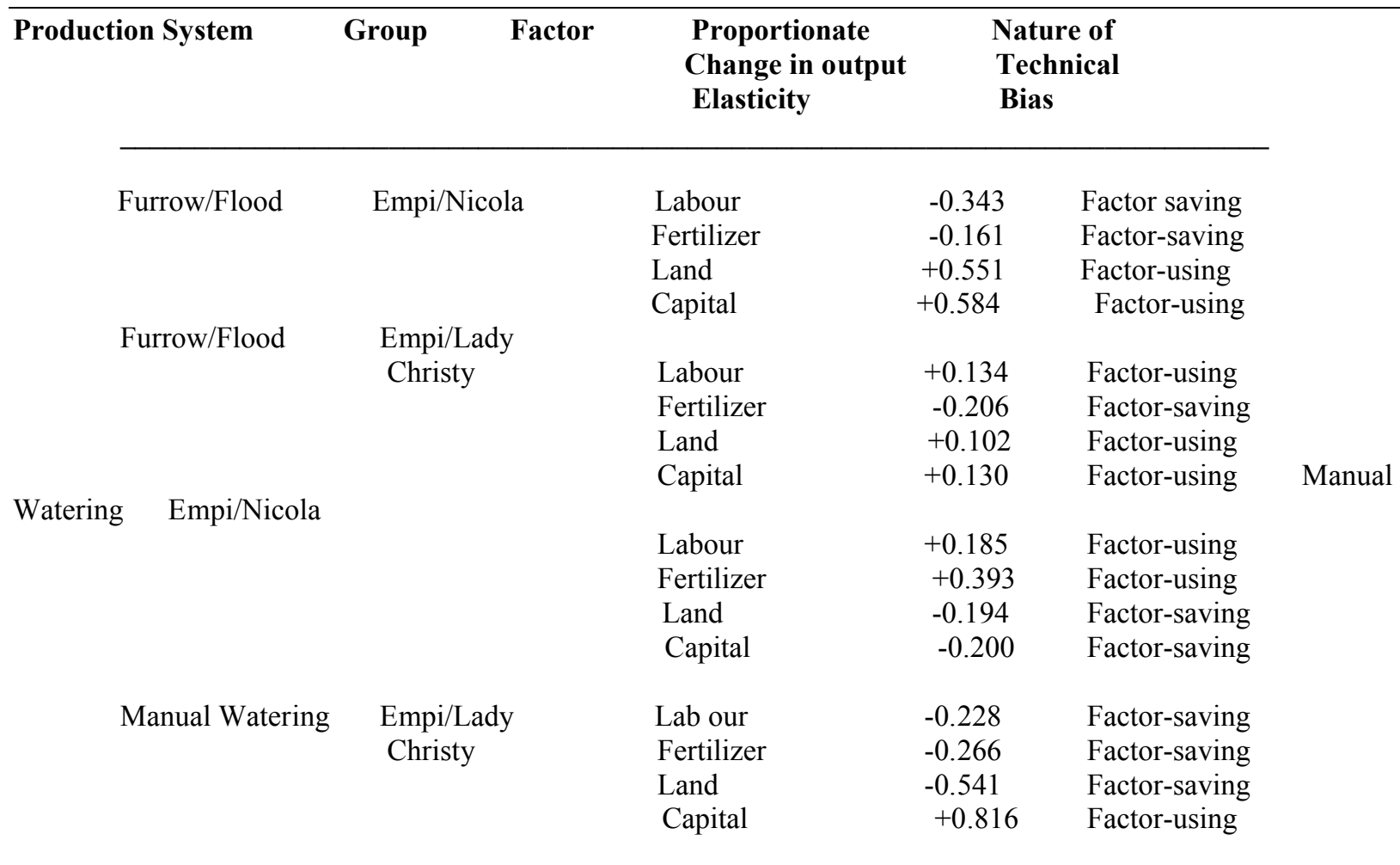

Source: Field Survey 2006.

Table 5 revealed that the introduction of high yielding Nicola potato variety to Jos Plateau was biased in favour of land and capital but against labour and fertilizer in the Furrow/Flood irrigation production system. Similarly, Lady Christy was biased in favour of land, capital and labour but against fertilizer. For Manual Watering production system, Nicola was biased in favour of capital but against labour, fertilizer and land.

\section{Percentage Change In Absolute Factor Shares in Potato production.}

Figures in Table 6 gave the absolute factor shares per hectare and percentage change in absolute factor shares under different groups of potato technologies. Almost all the factors of production gained under the new production technology in absolute terms but the percentage gain varied between factors and technology groups. The absolute shares of all factors of production were higher for Nicola and Lady Christy. For Nicola and Lady Christy under Furrow/Flood irrigation production system, the maximum percentage gain accrued to labour and fertilizer. The rise in the absolute share of labour was attributed to the rise in employment per hectare. The introduction of high yielding potato varieties (Nicola and Lady Christy) provided more employment opportunities for farm labourers. However, under Manual Watering production system, fertilizer and capital have maximum percentage gain. Technical change in potato production increased income to labour (from $81 \%$ to $132 \%$ ), fertilizer (from $29 \%$ to $151 \%$ ), land (from $-19 \%$ to $327 \%$ ) and capital (from $44 \%$ to $336 \%$ ). 
Journal Of Agriculture and Social Research (JASR) Vol. 8, No.1, 2008

Table 6: $\quad$ Percentage Change in absolute Factor Shares in Potato Production.

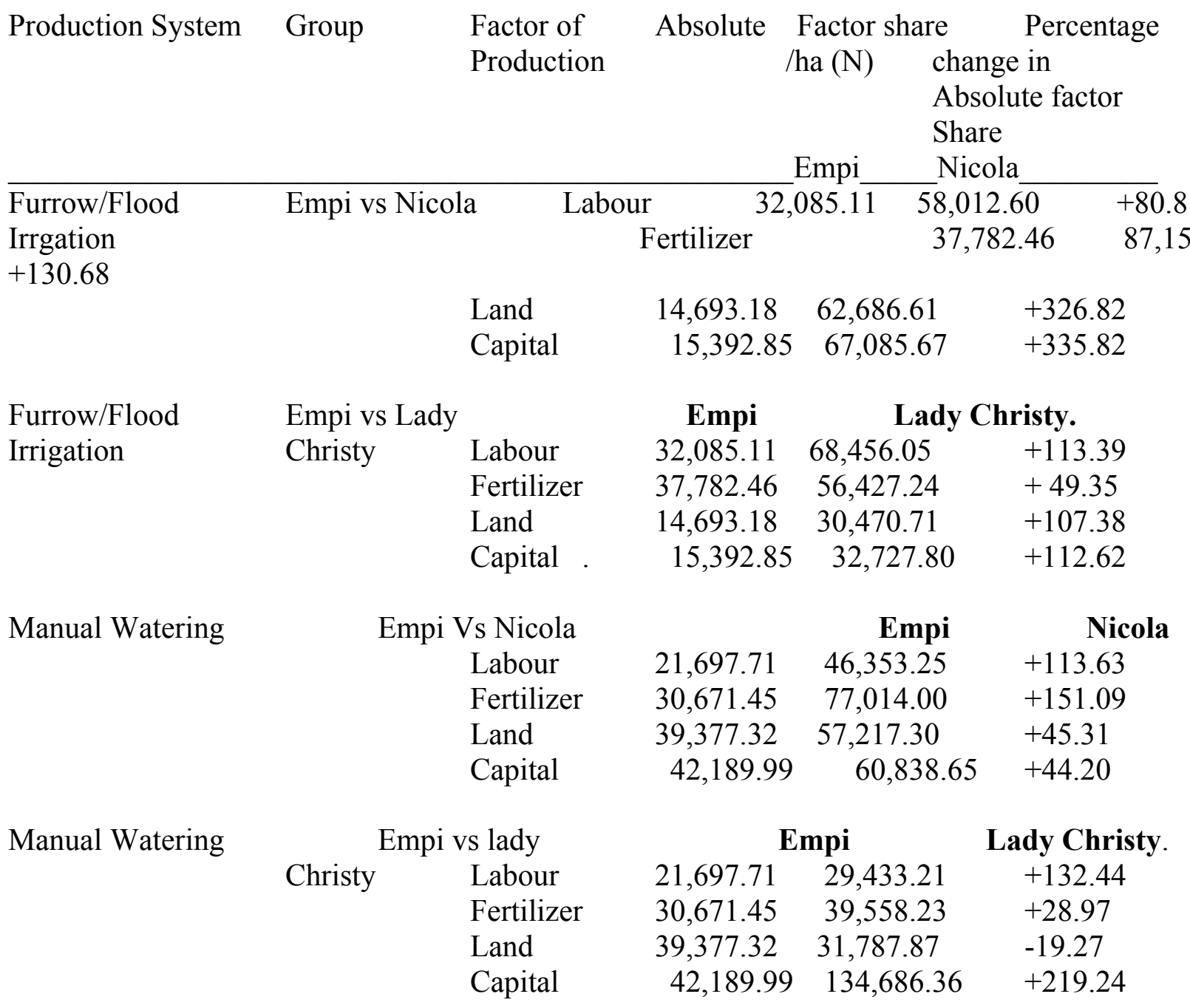

\section{Source: Field Survey, 2006.}

\section{CONCLUSION}

The technological change biases introduced by different potato varieties under the different production systems were as factor-saving as they were factor-using. The potato technology was land and capital - using but fertilizer and labour - saving.

From the results obtained in this study, the introduction of high yielding Nicola potato variety into Jos Plateau was biased in favour of land and capital but against labour and fertilizer in Furrow/Flood irrigation production system. The land-augmenting technological change has increased the income of owner farmers and landless labourers and widened the income disparities between large landowner farmers and the landless labourers.

\section{REFERENCES}

Alshi, M. R, Kumar. P and Mathur V. C. (1981). Technological Change and Factor Shares In Cotton Production: A Case Study of Akola Cotton Farms. Indian Journal of Agricultural Economics. 36 (3): 407-415

FAO(2004). Food and Agriculture Organization Crop Production Stastistics. 


\section{Journal Of Agriculture and Social Research (JASR) Vol. 8, No.1, 2008}

Fawole, O. P. and Akoroda; M. O. (2000). Socio-Economic Constraints to Potato Production, Processing and Marketing in Nigeria. In: Proceedings of $5^{\text {th }}$ Triennial Congress of the African Potato Association. Kampala, Uganda. Pp 445 - 448.

Lau.L.J and P.A. Yotopoulos (1972). Profit, Supply and Factor Demand Functions. American Journal of Agricultural Economics. 54 (1): 11-18.

Okonkwo, J. C. (1992). Potato Production In Nigeria. Training Workshop Paper, International Potato Center (CIP). In-Country Training at National Root Crops Research Institute, Vom, Nigeria.

Okonkwo, J. C., Ene, L. S. O. and O. O. Okoli (1995a). Potato Production in Nigeria. Published by NRCRI, Umudike. 109 pages.

Okonkwo, J .C, Ene L. S. O. and O. O. Okoli (1995b). Potato Production in Jos Plateau. Published by NRCRI, Umudike.34 pages.

Sankhayan,P .L.(1988). Introduction to The Economics of Agricultural Production. Eastern Economy Edition. 135 pages.

Stanton, W. R (1960). Potato Culture In Northern Nigeria. Newsletter. (17). 